\title{
Herpes labialis and Nigerian dental health care providers: knowledge, attitudes, behaviors, and refusal to treat
}

\author{
Clement Chinedu Azodo* and Agnes O. Umoh
}

\begin{abstract}
Background: The few existing studies on herpes labialis among health care workers have been predominantly among non-dental health care workers. The purpose of this study was to determine Nigerian dental health care providers' knowledge of, attitudes toward, preventive behaviors for, and refusal to treat patients with herpes labialis.

Methods: This cross-sectional study was conducted among final-year dental students at the University of Benin, dental house officers, and residents at the University of Benin Teaching Hospital, Benin City, Nigeria. Data collection was via a self-administered questionnaire. Bivariate statistics and logistic regression were used to relate the dependent and independent variables.

Results: Of the 120 questionnaires distributed, 110 were completed and returned, giving a $91.7 \%$ retrieval rate. However, 15 of the returned questionnaires were discarded because they were improperly completed, leaving a total of 95 questionnaires for final analysis in this study. The majority of participants were over 28 years old (54.7\%), male $(67.4 \%)$, unmarried (66.3\%), and postgraduate dental health care providers (51.6\%). Less than half (43.2 \%) of participants demonstrated adequate overall knowledge of herpes labialis. About one-tenth (10.5\%) and more than three-quarters (87.4\%) of participants reported a positive attitude and performance of adequate preventive behaviors, respectively. A total of $16.8 \%$ of participants reported a high tendency to refuse treatment to patients with herpes labialis. Although not statistically significant, young, unmarried, male undergraduate participants reported a greater likelihood to refuse treatment to herpes labialis patients. We found a statistically significant positive correlation between attitude and refusal to treat patients with herpes labialis. However, marital status and the attitude of participants toward these patients emerged as the determinants for refusal to treat patients with herpes labialis.

Conclusions: Data from this study revealed a high level of inadequate knowledge, negative attitudes, and reasonably adequate preventive behaviors with respect to herpes labialis. One out of every six dental health care workers studied reported having refused to treat patients with herpes labialis. Unmarried dental health care providers and those with negative attitudes toward herpes labialis patients were more prone to refuse treatment to these patients.
\end{abstract}

\section{Background}

Herpes labialis is a recurrent, self-limiting, infectious, vesiculo-ulcerative herpes simplex virus (HSV) infection that usually affects the lips and adjacent skin. The condition is considered a global problem [1]. It is usually transmitted by direct contact with the lesions or body fluids of an infected individual, although transmission through skin-to-skin contact during periods of

\footnotetext{
* Correspondence: clement.azodo@uniben.edu

Department of Periodontics, School of Dentistry, University of Benin, Ugbowo, Benin City, Edo State 300001, Nigeria
}

asymptomatic HSV shedding is also possible. These modes of transmission pose a serious risk to dental health care professionals for infection with herpes labialis. The literature includes reports of herpes whitlow and herpes keratitis in dental health care providers after treating patients with active herpes lesions, in the absence of proper infection control practices [2, 3]. Although barrier protection methods are the most reliable manner of preventing herpes infection, these do not completely eliminate the risk of transmission. It is therefore anticipated that the risk of infection influences the willingness of dental health care workers to treat 
Table 1 Demographic characteristics of participants

\begin{tabular}{lll}
\hline Characteristics & $\begin{array}{l}\text { Frequency } \\
(n)\end{array}$ & $\begin{array}{l}\text { Percent } \\
(\%)\end{array}$ \\
\hline Age (years) & 43 & 45.3 \\
$\leq 28$ & 52 & 54.7 \\
$>28$ & & \\
Sex & 64 & 67.4 \\
Male & 31 & 32.6 \\
Female & & \\
Marital status & 63 & 66.3 \\
Unmarried & 32 & 33.7 \\
Married & & \\
Professional status & 46 & 48.4 \\
Undergraduate & 49 & 51.6 \\
Postgraduate & 95 & 100.0 \\
Total & & \\
\hline
\end{tabular}

patients with herpes labialis, in the same way as when treating patients with other bloodborne viral infections.

Previous reports of unwillingness by dentists to treat patients with infectious diseases have mainly been related to infection with human immunodeficiency virus (HIV), hepatitis $\mathrm{B}$ virus (HBV) and hepatitis $\mathrm{C}$ virus (HCV) [4-7]. Refusal to treat patients with HIV has primarily been associated with a lack of ethical responsibility and fears related to cross infection [4]. It has been documented that dental students with poorer knowledge significantly preferred not to treat intravenous drug users and patients with hepatitis because of a perceived higher risk of infection [8].

Prominent herpes labialis lesions on the lip and associated pain alter physical appearance, cause psychological problems, interfere with social activities, and consequently impair quality of life $[9,10]$. Depression, isolation, fear of rejection, and self-destructive feelings are among the social and psychological consequences of herpes labialis, although these usually lessen over time. The refusal to treat patients with herpes labialis will therefore not only exert a negative impact on the overall health of affected individuals but will also limit dentists' contribution to infectious diseases control [6]. Such refusal to treat is unethical and may be viewed as discriminatory by the public, thus sowing distrust in the dentist-patient relationship and hampering communication, which will ultimately undermine optimal dental health care delivery $[11,12]$.

Studies on herpes labialis have been predominantly among non-health care workers, and the few studies in health care workers have involved non-dental health care workers. The only relevant previous study compared knowledge, attitudes and professional behaviors in relation to herpes labialis among dental and dental hygiene students at different academic levels [13]. However, that study assessed neither the determinants for refusal to treat patients with herpes labialis nor the trigger factors among participants. In that study, the null hypothesis was stated thus: no significant difference exists in the refusal to treat herpes labialis patients between participants with adequate and inadequate overall knowledge. Our proposed hypothesis is as follows: a significant difference exists in the refusal to treat herpes labialis patients between participants with adequate and inadequate overall knowledge. The purpose of this study was to determine Nigerian dental health care providers' knowledge of, attitudes toward, preventive behaviors for, and refusal to treat patients with herpes labialis.

\section{Methods}

Ethical considerations

The protocol for this study was reviewed and approved by the Ethics and Research Committee of the University of Benin Teaching Hospital in Benin City, Nigeria. Verbal informed consent was obtained from the participants. Participation in the study was voluntary and no incentive was offered.

\section{Study design}

This was a cross-sectional study conducted in June 2014 among final-year dental students of the University of Benin, and dental house officers and residents at the University of Benin Teaching Hospital, Nigeria.

\section{Sample size}

The sample size of 106 was determined using the Cochran formula for sample size calculation in epidemiological studies, based on the unpublished $7.4 \%$ self-reported annual prevalence of herpes labialis in this group [14]. However, the 120 distributed questionnaires eventually compensated for non-response.

\section{Selection criteria}

All final-year dental students at the University of Benin, as well as dental house officers and residents at the University of Benin Teaching Hospital who were available during the study and who consented, were selected. Those who were absent or did not consent to the study were excluded.

\section{Data collection}

The data collection tool used was a 40-item selfadministered validated questionnaire (see Additional file 1). The questionnaire was anonymous without any identifiers. A total of 19 items on our questionnaire were obtained 
Table 2 Knowledge of, attitudes toward, professional behaviors for, and refusal to treat patients with herpes labialis among participants

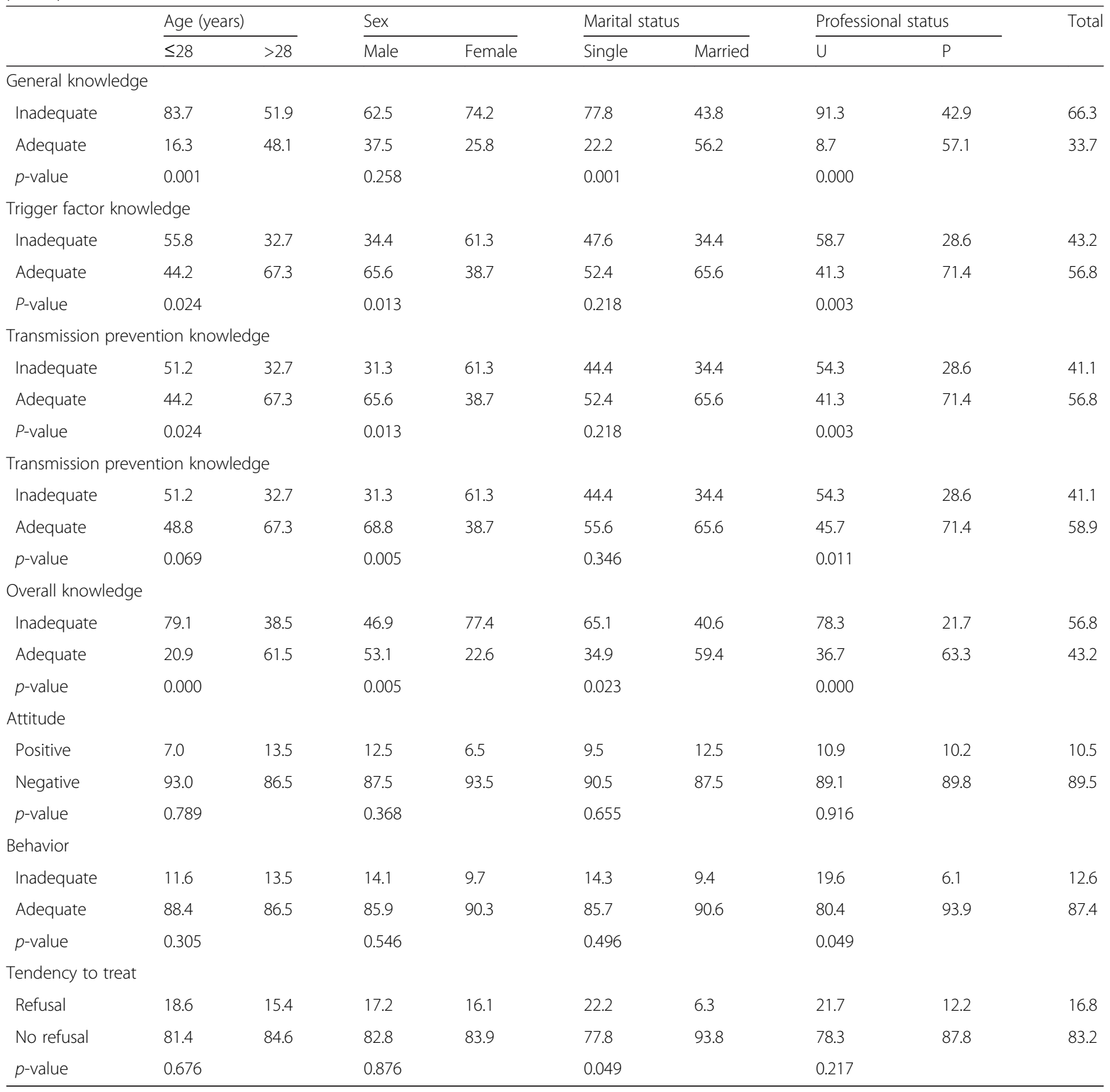

$U$ undergraduate, $P$ postgraduate

from that of Kanjirath et al. [13] which addressed knowledge, attitudes and professional behavior with respect to herpes virus.

Questionnaires were administered to dental students, and dental house officers and postgraduate residents during regular scheduled classes and postgraduate seminars, respectively. Completed questionnaires were collected immediately afterward.

\section{Data analysis}

The data obtained were subjected to descriptive, correlation and binary regression statistical analysis using Statistical Package for the Social Sciences (SPSS) Version 17.0 (SPSS Inc., Chicago, IL, USA). Participant age was categorized based on the previous experience of the authors. Data regarding knowledge, attitude, professional behaviors, and refusal tendency were dichotomized based on mean values 
Table 3 Bivariate correlation of demographic characteristics, knowledge, attitudes, behaviors, and refusal to treat patients with herpes labialis among participants

\begin{tabular}{|c|c|c|c|c|c|c|c|c|c|c|c|c|}
\hline Variable & & Age & Sex & $\begin{array}{l}\text { Marital } \\
\text { status }\end{array}$ & $\begin{array}{l}\text { Professional } \\
\text { status }\end{array}$ & $\begin{array}{l}\text { Overall } \\
\text { knowledge }\end{array}$ & $\begin{array}{l}\text { General } \\
\text { knowledge }\end{array}$ & $\begin{array}{l}\text { Trigger } \\
\text { knowledge }\end{array}$ & $\begin{array}{l}\text { Prevention } \\
\text { knowledge }\end{array}$ & Attitude & Behavior & $\begin{array}{l}\text { Refusal } \\
\text { to treat }\end{array}$ \\
\hline \multirow[t]{2}{*}{ Age } & $r$ & 1 & -.179 & $.469^{\mathrm{a}}$ & $.473^{\mathrm{a}}$ & $.408^{\mathrm{a}}$ & $.335^{\mathrm{a}}$ & $.232^{\mathrm{b}}$ & .187 & .105 & -.027 & -.043 \\
\hline & $p$-value & & .083 & .000 & .000 & .000 & .001 & .023 & .070 & .310 & .792 & .680 \\
\hline \multirow[t]{2}{*}{ Sex } & $r$ & -.179 & 1 & .122 & -.089 & $-.289^{a}$ & -.116 & $-.255^{\mathrm{b}}$ & $-.286^{\mathrm{a}}$ & -.092 & .062 & -.013 \\
\hline & $p$-value & .083 & & .241 & .389 & .004 & .263 & .013 & .005 & .373 & .551 & .899 \\
\hline \multirow[t]{2}{*}{ Marital status } & $r$ & $.469^{\mathrm{a}}$ & .122 & 1 & $.557^{\mathrm{a}}$ & $.233^{b}$ & $.340^{\mathrm{a}}$ & .126 & .097 & .046 & .070 & $-.202^{b}$ \\
\hline & $p$-value & .000 & .241 & & .000 & .023 & .001 & .222 & .351 & .659 & .501 & .050 \\
\hline \multirow{2}{*}{$\begin{array}{l}\text { Professional } \\
\text { status }\end{array}$} & $r$ & $.473^{a}$ & -.089 & $.557^{\mathrm{a}}$ & 1 & $.419^{a}$ & $.512^{\mathrm{a}}$ & $.304^{a}$ & $.262^{\mathrm{b}}$ & -.011 & $.202^{b}$ & -.127 \\
\hline & $p$-value & .000 & .389 & .000 & & .000 & .000 & .003 & .010 & .917 & .049 & .221 \\
\hline \multirow{2}{*}{$\begin{array}{l}\text { Overall } \\
\text { knowledge }\end{array}$} & $r$ & $.408^{\mathrm{a}}$ & $-.289^{a}$ & $.233^{\mathrm{b}}$ & $.419^{a}$ & 1 & $.593^{\mathrm{a}}$ & $.631^{\mathrm{a}}$ & $.684^{\mathrm{a}}$ & -.022 & .075 & -.051 \\
\hline & $p$-value & .000 & .004 & .023 & .000 & & .000 & .000 & .000 & .833 & .468 & .621 \\
\hline \multirow{2}{*}{$\begin{array}{l}\text { General } \\
\text { knowledge }\end{array}$} & r & $.335^{\mathrm{a}}$ & -.116 & $.340^{\mathrm{a}}$ & $.512^{\mathrm{a}}$ & $.593^{\mathrm{a}}$ & 1 & $.396^{a}$ & $.414^{a}$ & -.172 & .003 & -.023 \\
\hline & $p$-value & .001 & .263 & .001 & .000 & .000 & & .000 & .000 & .096 & .978 & .824 \\
\hline \multirow{2}{*}{$\begin{array}{l}\text { Trigger } \\
\text { Knowledge }\end{array}$} & $r$ & $.232^{\mathrm{b}}$ & $-.255^{b}$ & .126 & $.304^{\mathrm{a}}$ & $.631^{\mathrm{a}}$ & $.396^{\mathrm{a}}$ & 1 & $.915^{\mathrm{a}}$ & .022 & .117 & .108 \\
\hline & $p$-value & .023 & .013 & .222 & .003 & .000 & .000 & & .000 & .833 & .261 & .297 \\
\hline \multirow{2}{*}{$\begin{array}{l}\text { Prevention } \\
\text { Knowledge }\end{array}$} & r & .187 & $-.286^{a}$ & .097 & $.262^{b}$ & $.684^{a}$ & $.414^{a}$ & $.915^{\mathrm{a}}$ & 1 & .007 & .134 & .090 \\
\hline & $p$-value & .070 & .005 & .351 & .010 & .000 & .000 & .000 & & .944 & .197 & .387 \\
\hline \multirow[t]{2}{*}{ Attitude } & r & .105 & -.092 & .046 & -.011 & -.022 & -.172 & .022 & .007 & 1 & -.076 & $.212^{\mathrm{b}}$ \\
\hline & $p$-value & .310 & .373 & .659 & .917 & .833 & .096 & .833 & .944 & & .464 & .039 \\
\hline \multirow[t]{2}{*}{ Behavior } & r & -.027 & .062 & .070 & $.202^{\mathrm{b}}$ & .075 & .003 & .117 & .134 & -.076 & 1 & .171 \\
\hline & $p$-value & .792 & .551 & .501 & .049 & .468 & .978 & .261 & .197 & .464 & & .097 \\
\hline \multirow{2}{*}{$\begin{array}{l}\text { Refusal to } \\
\text { treat }\end{array}$} & r & -.043 & -.013 & $-.202^{b}$ & -.127 & -.051 & -.023 & .108 & .090 & $.212^{b}$ & .171 & 1 \\
\hline & $p$-value & .680 & .899 & .050 & .221 & .621 & .824 & .297 & .387 & .039 & .097 & \\
\hline
\end{tabular}

${ }^{\text {a }}$ Correlation is significant at the 0.01 level (2-tailed)

${ }^{\mathrm{b}}$ Correlation is significant at the 0.05 level (2-tailed)

obtained from the pilot study. The mean values were rounded up to the nearest whole number and considered to be the lower limits of adequate, positive, and high categories of knowledge/behavior, attitude and refusal to treat, respectively. In the binary regression analysis, refusal to treat was the dependent variable whereas demographic characteristics, overall knowledge, attitude, and professional behavior were independent variables. Statistical significance was set at $p<0.05$.

\section{Results}

Of the 120 questionnaires distributed, 110 were returned completed, giving a $91.7 \%$ retrieval rate. However, 15 of the returned questionnaires were discarded because they were improperly filled out, leaving a total of 95 questionnaires for final analysis in this study (Additional file 2).

\section{Demographic characteristics of participants}

The majority of participants were over 28 years old (54.7\%), male (67.4\%), unmarried (66.3\%), and postgraduate dental health care providers $(51.6 \%)$ (Table 1$)$.

\section{Participant knowledge, attitudes, professional behaviors, and refusal to treat}

General knowledge about herpes was adequate in $33.7 \%$ of participants and was significantly associated with age, marital status, and professional status. Trigger knowledge was adequate in $56.8 \%$ of participants and was significantly associated with age, sex, and professional status. Knowledge about transmission prevention was adequate in $58.9 \%$ of participants and significantly associated with sex and professional status. Overall knowledge was adequate in $43.2 \%$ of participants and significantly associated with age, sex, marital status, and professional status. A positive attitude was found in $10.5 \%$ of participants and this was not significantly 
Table 4 Determinants of refusal to treat patients with herpes labialis among participants, using binary regression

\begin{tabular}{|c|c|c|c|c|c|c|}
\hline Variable & B & S.E. & Wald & OR & $95 \% \mathrm{Cl}$ & $p$-value \\
\hline Age & 0.995 & 0.818 & 1.479 & 2.704 & $0.544-13.431$ & 0.224 \\
\hline Sex & 0.308 & -0.745 & 0.172 & 1.361 & $0.316-5.857$ & 0.679 \\
\hline Marital status & -2.179 & 1.067 & 4.174 & 0.113 & $0.014-0.915$ & 0.041 \\
\hline Professional status & -1.135 & 0.933 & 1.478 & 0.321 & $0.052-2.003$ & 0.224 \\
\hline Overall knowledge & -1.510 & 1.053 & 2.057 & 0.221 & $0.0281-.739$ & 0.151 \\
\hline General knowledge & 1.710 & 1.084 & 2.490 & 5.527 & $0.661-46.225$ & 0.115 \\
\hline Trigger knowledge & 1.929 & 2.578 & 0.560 & 6.882 & $0.04-1076.210$ & 0.454 \\
\hline Prevention knowledge & -0.722 & 2.606 & 0.077 & 0.486 & $0.003-80.226$ & 0.782 \\
\hline Attitude & 2.257 & 0.957 & 5.558 & 9.554 & $1.463-62.380$ & 0.018 \\
\hline Behavior & 20.752 & 10430.160 & 0.000 & 1.029E9 & $0.000-$ & 0.998 \\
\hline Constant & -45.131 & 20860.321 & 0.000 & 0.000 & - & 0.998 \\
\hline
\end{tabular}

Ref. age = $\leq 28$ years; sex = male; marital status = unmarried; professional status = - undergraduate; overall knowledge = inadequate; general knowledge = inadequate; trigger knowledge = inadequate; prevention knowledge = inadequate; attitude $=$ positive; behavior $=$ inadequate OR Odds Ratio, CI Confidence Interval, $B$ intercept, S.E. standard error, Wald Wald chi-square test

associated with demographic characteristics. Professional behavior was adequate in $87.4 \%$ of participants. The refusal to treat patients with herpes labialis was reported in $16.8 \%$ of participants (Table 2).

\section{Bivariate correlation of participant demographic characteristics, knowledge, attitudes, behaviors, and refusal to treat herpes labialis patients}

Overall knowledge had a significant positive correlation with age, sex, marital status, professional status, general knowledge, trigger knowledge, and prevention knowledge. Although overall knowledge was negatively correlated with attitude and refusal to treat, this was not statistically significant. Refusal to treat only had a significant positive correlation with attitude (Table 3 ).

\section{Determinants of participants' refusal to treat herpes labialis patients using binary regression}

The determinants of refusal to treat patients with herpes labialis were marital status $(p=0.041$, O.R $=0.113,95 \%$ C.I $=0.014-0.915)$ and attitude toward patients with herpes labialis $(p=0.018$, O. $\mathrm{R}=9.554,95 \%$ C.I $=1.463-$ 62.380) (Table 4).

\section{Discussion}

Delivery of oral health care is the fundamental responsibility of dentists. However, these professionals are at risk for infections caused by various microorganisms such as Mycobacterium tuberculosis, HBV and HCV, staphylococci, streptococci, HSV type 1, HIV, mumps, influenza, and rubella $[15,16]$. Herpes viruses shed in saliva can cause persistent infections in most exposed individuals, thus making such exposure a concern in dentistry [17]. Previous reports have indicated that the mechanisms, routes and risks of transmission of important viral pathogens encountered in dental practice are not clearly understood $[18,19]$. In this study, more than half of the participants exhibited adequate herpes labialis trigger factor and transmission prevention knowledge, but only one-third (33.7 \%) had adequate general knowledge about herpes labialis. These findings contrast with reports of good knowledge about the etiology, transmission pattern, and prevention of other bloodborne viral infections among most dentists in Italy and Pakistan $[20,21]$.

Preventing cross infection is considered an essential aspect of dental practice because disease transmission may occur this way in the dental health care setting. A prerequisite to understanding the need for infection control practices in dentistry is a sound knowledge of infectious diseases and their transmission potential in the oral health care setting [18]. In this study, adequate overall knowledge about herpes labialis was found in less than half (43.2\%) of participants. This is considered low for dental health care workers because inadequate knowledge may lead to suboptimal infection control practices with consequent infection in the form of herpetic whitlow and herpetic keratitis. This result also reflects insufficient understanding of herpes labialis among our participants. We found that less than $65 \%$ of participants had good knowledge of $\mathrm{HIV}, \mathrm{HBV}$, and $\mathrm{HCV}$, the bloodborne viral infections focused on by Kadeh et al. [22] in their study among Iranian dentists. The low proportion of adequate general, trigger factor, and transmission prevention knowledge of herpes labialis among our participants explains the low prevalence of adequate overall knowledge of herpes labialis. This is confirmed by the statistically significant positive correlation between overall knowledge, general, trigger factor, and transmission prevention knowledge in this study. The significant positive correlation between overall 
knowledge, age, sex, marital status, and professional status is consistent with reports of significant correlations between professional status and knowledge of $\mathrm{HIV}, \mathrm{HBV}$, and $\mathrm{HCV}$ infections among Italian and Iraqi dentists [20, 23].

The source of infection in dentistry may be the dental health care providers or patients with infectious diseases either in the prodromal stage or carrier (convalescent or asymptomatic) state. The reluctance of dentists to treat patients with infectious disease represents a major concern. Refusing treatment to patients whose infective status is definitive is not only unethical but also illogical because undiagnosed carriers of infectious disease pass undetected through dental health care settings daily $[24,25]$. In this study, $16.8 \%$ of participants reported a high likelihood of refusing treatment to patients with herpes labialis. Similarly, $16.0 \%$ of Canadian and Indian dentists were unwilling to treat HIVinfected patients $[4,26]$. However, Khosravanifard et al. $[6,7]$ reported $85.1 \%$ and $44.4 \%$ of Iranian dentists refused treatment for simulated HIV-positive patients and HBV-infected patients, respectively. This finding was higher than reported values among dental health care providers in Minnesota, United States (14.0 \%) [27], Italian dentists (4.5-9.4\%) [5, 28], and dental hygienists (5.9\%) [29]. A total of $5.0 \%$ of dental offices in Los Angeles County had an unlawful blanket policy of refusing dental services to people with HIV and AIDS [30]. Though not assessed in our study, this may be extended to other infectious diseases because medical students with career interests in surgical specialties (into which dentistry may be categorized) have indicated less willingness to provide care for patients with infectious diseases, presumably because of a perceived higher risk of exposure [31]. The successful resolution of concerns and enhancement of provider comfort levels with respect to treating patients with herpes labialis are therefore necessary to eliminate refusal to treat these patients and ensure appropriate patient care practices.

Although not statistically significant, young, unmarried, male undergraduate participants reported a higher likelihood of refusal to treat herpes labialis patients. There was a statistically significant positive correlation between attitudes and a tendency to refuse treatment to herpes labialis patients in this study. Refusal to treat patients with infectious disease results from a perceived stigma about treating such patients, discrimination, an absence of feeling ethical responsibility, a fear of being infected, and a lack of effective policies, proper knowledge, and appropriate facilities $[4,5,26,31,32]$.

Using binary regression, the determinants of refusal to treat herpes labialis patients were marital status and attitude toward herpes labialis. This can be explained by the fact that non-professional attitudes, low optimism scores, and low comfort levels were among the best predictors of belief in the right to refuse treatment to HIV-infected patients [33]. Reducing concerns and enhancing providers' comfort levels with respect to caring for patients with herpes labialis can help to reduce the tendency to refuse treatment to these patients. These were the parameters assessed in this study.

The findings of this study should be interpreted with caution because the analyzed information was selfreported and may be biased by underestimation, overestimation, and social desirability. In addition, the selfreported behavior of dental health care professionals may not necessarily reflect their actual behaviors $[6,7]$.

\section{Conclusion}

Data from this study revealed a high level of inadequate knowledge, negative attitudes, and reasonably adequate preventive behaviors regarding herpes labialis. One of every six dental health care workers studied reported having refused to treat patients with herpes labialis. Unmarried dental health care providers and those with negative attitudes toward patients with herpes labialis were more likely to refuse treatment to these patients.

\section{Additional files}

Additional file 1: Questionnaire. (DOCX $15 \mathrm{~kb}$ )

Additional file 2: Database for the study. (XLSX $19 \mathrm{~kb})$

\section{Competing interests}

The authors declare that they have no competing interests.

\section{Authors' contributions}

CCA conceived the study, made substantial contributions to the design and literature review, was involved in drafting the manuscript, and approved the final version to be published. AOU made substantial contributions to the study design and acquisition of data, was involved in drafting the manuscript, and approved the final version to be published. Both authors read and approved the final manuscript.

\section{Authors' information}

CCA holds a Bachelor of Dental Surgery (BDS) degree, Master of Physiology (MSc Physio.), Master of Public Health (MPH), and is a Fellow of the Medical College in Dental Surgery (FMCDS) of Nigeria. CCA lectures in Periodontics at the University of Benin and practices as a Consultant Periodontist at the University of Benin Teaching Hospital in Benin City, Nigeria. AOU holds a Bachelor of Dental Surgery (BDS) degree, and is a Fellow of the Medical College in Dental Surgery (FMCDS) of Nigeria. AOU lectures in Periodontics y at the University of Benin and practices as a Consultant Periodontist at the University of Benin Teaching Hospital in Benin City, Nigeria.

\section{Acknowledgements}

No external funding was received to conduct this study. The authors are grateful to the final-year dental students of the University of Benin, and to the dental house officers and residents of the University of Benin Teaching Hospital whose participation made this study possible. 
Received: 18 September 2014 Accepted: 24 August 2015

Published online: 15 September 2015

\section{References}

1. Raborn GW, Grace MG. Recurrent herpes simplex labialis: selected therapeutic options. J Can Dent Assoc. 2003;69(8):498-503.

2. Rowe NH, Heine CS, Kowalski CJ. Herpetic whitlow: an occupational disease of practicing dentists. J Am Dent Assoc. 1982;105(3):471-3.

3. Browning WD, McCarthy JP. A case series: herpes simplex virus as an occupational hazard. J Esthet Restor Dent. 2012;24(1):61-6.

4. McCarthy GM, Koval JJ, MacDonald JK. Factors associated with refusal to treat HIV-infected patients: the results of a national survey of dentists in Canada. Am J Public Health. 1999;89(4):541-5.

5. Giuliani M, Lajolo C, Sartorio A, Lacaita MG, Capodiferro S, Cauda R, et al. Attitudes and practices of dentists treating patients infected with human immunodeficiency virus in the era of highly active antiretroviral therapy. Med Sci Monit. 2009;15(6):H49-56.

6. Khosravanifard B, Rakhshan V, Ghasemi M, Pakdel A, Baradaran-Eghbal S, Sheikholeslami R, et al. Tehran dentists' self-reported knowledge and attitudes towards HIV/AIDS and observed willingness to treat simulated HIV-positive patients. East Mediterr Health J. 2012;18(9):928-34.

7. Khosravanifard B, Rakhshan V, Najafi-Salehi L, Sherafat S. Tehran dentists' knowledge and attitudes towards hepatitis $B$ and their willingness to treat simulated hepatitis B positive patients. East Mediterr Health J. 2014;20(8):498-507.

8. Brailo V, Pelivan I, Škaricić J, Vuletić M, Dulcić N, Cerjan-Letica G. Treating patients with HIV and Hepatitis B and C infections: Croatian dental students' knowledge, attitudes, and risk perceptions. J Dent Educ. 2011;75(8):1115-26.

9. Siegel MA. Diagnosis and management of recurrent herpes simplex infections. J Am Dent Assoc. 2002:133(9):1245-9.

10. Arduino PG, Porter SR. Oral and perioral herpes simplex virus type 1 (HSV-1) infection: review of its management. Oral Dis. 2006;12(3):254-70.

11. Terry SD, Jones JE, Brown RH. Dental-care experiences of people living with HIV/AIDS in Aotearoa New Zealand. N Z Dent J. 1994;90(400):49-55.

12. Giuliani M, Lajolo C, Rezza G, Arici C, Babudieri S, Grima P, et al. Dental care and HIV-infected individuals: are they equally treated? Community Dent Oral Epidemiol. 2005;33(6):447-53.

13. Kanjirath PP, Peters MC, Inglehart MR. Treating patients with herpes simplex virus infections: dental and dental hygiene students' knowledge, attitudes, and professional behavior. J Dent Educ. 2007;71(9):1133-44.

14. Cochran WG. Sampling techniques. 3rd ed. New York: Wiley; 1977. p. 428.

15. Walkinson AC. Primary herpes simplex in a dentist. Br Dent J. 1982;153(5):190-1.

16. Kohn WG, Harte JA, Malvitz DM, Collins AS, Cleveland JL, Eklund KJ. Centers for disease control and prevention. Guidelines for infection control in dental health care settings-2003. J Am Dent Assoc. 2004;135(1):33-47.

17. Merchant VA. Herpes viruses and other microorganisms of concern in dentistry. Dent Clin North Am. 1991;35(2):283-98.

18. Epstein JB, Mathias RG, Gibson GB. Survey to assess dental practitioner's knowledge of infectious disease. J Can Dent Assoc. 1995;61(6):519-25.

19. Epstein JB, Mathias RG, Bridger DV. Survey of knowledge of infectious disease and infection control practices of dental specialists. J Can Dent Assoc. 1995;61(1):35-7. 40-44.

20. Vitale F, Di Benedetto MA, Casuccio A, Firenze A, Calandra G, Ballarò F, et al. The influence of professional degree on the knowledge of HIV, HBV and HCV infections in dentistry practice. Ann Ig. 2005;17(3):185-96.

21. Batoo A, Sherwani MU, Bano KA, Aasim M. Knowledge, attitude and practices of dentists about Hepatitis B and C infection in Lahore. Pak J Med Res. 2012;51(3):93-6.

22. Kadeh H, Saravani S, Golzari P. Knowledge, attitude and practice of dentists towards patients with HIV, Hepatitis B and Hepatitis C infections. Avicenna J Dent Res. 2014;6(1), e21348.

23. Al-Sandook T, Al-Naimi R, Younis M. An investigation of dentists knowledge, attitude and practices towards HIV+ and patients with other blood borne viruses in Mosul City. Al-Rafidain Den J. 2013;10(2):298-308.

24. General Dental Council. Standards for dental professionals. 2005. http://www.gdc-uk.org/Dentalprofessionals/Standards/Documents/ Standards\%20for\%20Dental\%20Professionals.pdf.

25. British Dental Association. Infection control in dentistry. England: BDA Advice sheet A12; 2009.
26. Bodhade A, Dive A, Khandekar S, Dhoble A, Moharil R, Gayakwad R, et al. Factors associated with refusal to treat HIV-infected patients: National survey of dentists in India. Sci J Public Health. 2013;1 (2):51-5.

27. Hastreiter RJ, Roesch MH, Danila RN, Falken MC. Dental health care workers' response to the HIV epidemic. Am J Dent. 1992;5(3):160-6.

28. Angelillo IF, Villari P, D'Errico MM, Grasso GM, Ricciardi G, Pavia M. Dentists and AIDS: a survey of knowledge, attitudes, and behavior in Italy. J Public Health Dent. 1994:54(3):145-52.

29. Giuliani M, Tumbarello M, Marino M, Capodiferro S, Scivetti M, Rezza G, et al. Dental hygienists behaviour towards HIV-positive patients in highly active antiretroviral therapy era: a pilot survey. Int J Dent Hyg. 2011;9(3):204-10.

30. Sears B, Cooper C, Younai FS, Donohoe T. HIV discrimination in dental care: results of a discrimination testing study in Los Angeles County. 2011. p. 1-32.

31. Weyant RJ, Simon MS, Bennett ME. Changes in students' attitudes toward HIV-infected patients as the students progress through medical school. Acad Med. 1993;68(5):377-9.

32. Maupomé-Carvantes $\mathrm{G}$, Borges-Yáñez SA. Attitudes and habits for the control of HIV and hepatitis B in dental students. Salud Publica Mex. 1993;35(6):642-50

33. Bennett ME, Weyant RJ, Simon M. Predictors of dental students' belief in the right to refuse treatment to HIV-positive patients. J Dent Educ. 1993;57(9):673-9.

\section{Submit your next manuscript to BioMed Central and take full advantage of:}

- Convenient online submission

- Thorough peer review

- No space constraints or color figure charges

- Immediate publication on acceptance

- Inclusion in PubMed, CAS, Scopus and Google Scholar

- Research which is freely available for redistribution 